\title{
Species composition and abundance of the shallow water fish community of Kongsfjorden, Svalbard
}

\author{
Markus Brand $^{1}$ (B) $\cdot$ Philipp Fischer ${ }^{1}$
}

Received: 28 September 2015/Revised: 24 July 2016/Accepted: 11 August 2016

(C) Springer-Verlag Berlin Heidelberg 2016

\begin{abstract}
Projections show that climate change will lead to structural change in Arctic ecosystems. Studies project the extinction of local species and intense species invasion to the Arctic Ocean. A lack of basic biological data about the Arctic shallow water fish community will make it hard to assess whether these communities will change or not. Baseline studies in combination with future reassessments are needed to establish a basic knowledge about the change of these communities. This study provides a quantitative first time description of the shallow water fish community of Kongsfjorden, Svalbard. The fish assemblage in the depth range from 3 to $12 \mathrm{~m}$ was determined with respect to abundance and species composition. Among a total sample size of 2804 specimens, the presence of 12 fish species and one family (Liparidae) was detected. Myoxocephalus scorpius (shorthorn sculpin) (74.9\%), Gadus morhua (Atlantic cod) (17.2\%), and Gymnocanthus tricuspis (Arctic staghorn sculpin) (3.8\%) were identified as the most abundant species across all sampling sites. A significant relationship between algal coverage and fish abundance was detected. Furthermore, we demonstrated a fjord inward increase in biodiversity along the south shore that might be correlated with a change in hydrographic regime.
\end{abstract}

This article belongs to the special issue on the "Kongsfjorden ecosystem-new views after more than a decade of research", coordinated by Christian Wiencke and Haakon Hop.

Markus Brand

mail@markusbrand.de; markus.brand@awi.de

1 Biologische Anstalt Helgoland, Centre for Scientific Diving, Alfred-Wegener-Institut Helmholtz-Zentrum für Polar- und Meeresforschung, Kurpromenade 201, 27498 Helgoland, Germany
Keywords Demersal $\cdot$ Sublittoral $\cdot$ Coastal habitats · Algal belts $\cdot$ Species diversity

\section{Introduction}

It is known that climate change can impact the marine biodiversity through changes in species distribution. Existing projections for marine fish and invertebrates show local species extinctions and intense species invasions into the Arctic Ocean (Cheung et al. 2009). Consequently, Arctic fishes might not just experience a change of hydrographic regime, but may also face new ecological interactions (Fossheim et al. 2015). Due to a lack of basic ecological data about Arctic fishes, the consequence for ecosystem structure and function is unclear (Christiansen et al. 2014). A possible scenario is the retreat of Arctic shelf fish species northwards towards the polar basin and a borealisation of the southern communities (Fossheim et al. 2015). However, a thorough quantitative assessment of Arctic fish communities, to which future investigations can be compared, has hitherto been lacking especially for Arctic shallow water habitats. This study aims to provide this description for the shallow water habitat of Kongsfjorden.

Kongsfjorden on the west coast of Spitsbergen (Fig. 1) has been the focus of ecological research in the Arctic for several decades. Geographically, Kongsfjorden at $79^{\circ} \mathrm{N}$ is classified as Arctic; however, it is in fact significantly influenced not only by Arctic but also by Atlantic water masses from the Fram Strait (Hop et al. 2002). The $20 \mathrm{~km}$ long fjord opens to a shelf system in a westerly direction without a sill and shares this outlet with the more northern Krossfjorden (Cottier et al. 2005). Additionally, an underwater canyon runs from the outlet across the shelf to the 

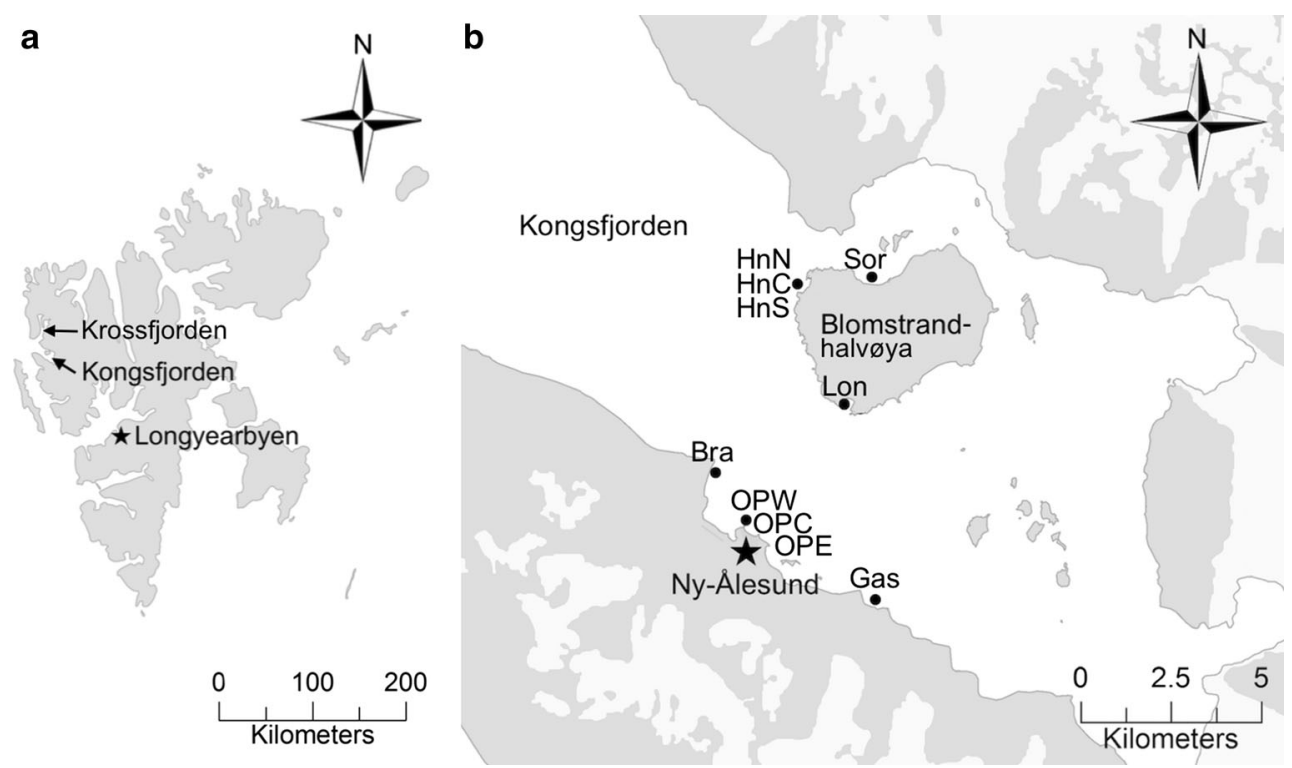

Fig. 1 a Map of the Svalbard archipelago with its main settlement Longyearbyen and the site of study, Kongsfjorden. b Map of Kongsfjorden with its settlement Ny-Ålesund and the island Blomstrandhalvøya. Light areas on land indicate glacier surfaces. The sampling sites are marked with abbreviations: Sor-Sørvågen, HnN-Hansneset North, HnC-Hansneset Central, HnS-Hansneset

continental edge, establishing a connection to the deeper water masses off the shelf that belong to the West Spitsbergen Current. Complex mixing processes between the Arctic shelf water masses, the Atlantic deep water masses, and the highly seasonal fresh water run-off from the inner part of the fjord result in steep environmental gradients from the inner parts of the fjord up to its mouth (Svendsen et al. 2002). Willis et al. (2006) suggest a general counterclockwise circulation pattern in Kongsfjorden for the transport and the mixing of those water masses with an influx of water along the south shore and an efflux along the north shore. The resulting hydrographic gradients and their short- and long-term changes in intensity have the potential to directly influence the pelagic and benthic realms of the fjord. Thereby, the local food web is influenced on a spatial and temporal scale (Stempniewicz et al. 2007).

The complex environmental interactions within the fjord result in a mixed species composition that includes Atlantic and Arctic species in close association. The study of this dynamic habitat and its ecological processes is potentially valuable to enhance the knowledge about the potential influence of hydrographic regime shifts on other Arctic ecosystems. The general differences and characteristics of each ecosystem will have to be carefully reviewed for such comparison, but in the context of a predicted rise of $3.7^{\circ} \mathrm{C}$ in mean air temperature in the Arctic over the next 50 years (ACIA 2004; Wong et al. 2014), Arctic marine
South, Lon-London, Bra-Brandal, OPW-Old Pier West, OPCOld Pier Central, OPE-Old Pier East, Gas—Gåsebu. The three sites at Hansneset and Old Pier were spaced approximately $100 \mathrm{~m}$ from each other. The map data were provided by the Norwegian Polar Institute

ecosystems might face similar long-term changes in their hydrographic regimes, e.g., a rise of sea surface temperature and a general decrease of ice cover potentially directly affecting the marine habitat and its fauna. In the outer part of Kongsfjorden, a close relationship between short-term hydrographical regime changes and the zooplankton abundance has already been shown by Willis et al. (2006). In contrast, Renaud et al. (2011) used stable isotope ratios to demonstrate relative little variability in food web structure of Kongsfjorden over the temporal and spatial scale of their study. In turn, Voronkov et al. (2013) showed for hard bottom zoobenthos a general decrease in species richness, frequency of occurrence, mean abundance, and biomass towards the tidal glaciers in inner Kongsfjorden. Hop et al. (2002) highlight the need to better understand the temporal and spatial dynamics of the secondary and tertiary consumers including zooplankton, crustaceans, fishes, birds, and mammals, as well as their interaction with the local hydrographical regime.

Previous fish community assessments in Kongsfjorden have been performed by trawling in the deeper parts of the fjord or by diving observations in the shallow areas (Hop, pers. comm.). Recent studies describe a total of about 30 Arctic, sub-Arctic, and boreal fish species for the entire fjord system. Typical species with an Arctic and sub-Arctic distribution are Boreogadus saida (polar cod), Eumicrotremus derjungini (leatherfin lumpsucker), G. tricuspis (Arctic staghorn sculpin), Lycodes reticulatus (Arctic 
eelpout), Mallotus villosus (capelin), Sebastes mentella (deepwater redfish), and Somniosus microcephalus (Greenland shark). Furthermore, generalist species of the North Atlantic can be found. These are G. morhua (Atlantic cod), M. scorpius (shorthorn sculpin), Anarhichas lupus (Atlantic wolfish), Leptoclinus maculatus (daubed shanny), Hippoglossoides platessoides (long rough dab), Leptagonus decagonus (Atlantic poacher), and the family of Liparidae (snailfishes) (Hop et al. 2002; Renaud et al. 2011). The shallow water habitat of Kongsfjorden has been described by SCUBA surveys as rich in macroalgal belts (Hop et al. 2012). Bartsch et al. (2016) showed for 2012 and 2013 that the maximum density of these kelp belts was found at a depth of $2.5 \mathrm{~m}$, with decreasing densities down to the maximum depth of the study at $15 \mathrm{~m}$. Jørgensen and Gulliksen (2001) described the seabed in depths between 16 and $30 \mathrm{~m}$ as highly structured and complex benthic habitat with a mixture of rocky bottom, ice-rafted pebbles and stones. Voronkov et al. (2013) report that the structural complexity of the seafloor is increased by crustose coralline algae, shell hash of molluscs, and barnacles. The maximum abundance and diversity of hard bottom fauna are described by Voronkov et al. (2013) for the depth range of 5-10 $\mathrm{m}$ in 1996-1998. The structure rich seafloor has the potential to represent an important habitat for fishes. Especially, the macroalgal belts provide additional structural protection from waves as well as currents, and the infauna is a potential food source (Lippert et al. 2001). The shallow water habitats are commonly considered to be areas of aggregation for the resident fish community due to their function as spawning and nursery grounds (Werner 1977; Werner et al. 1983; Keast 1985; Pierce et al. 1994; Fischer and Eckmann 1997a, b). By feeding in the macroalgal belts, the fish community acts as a secondary producer in the local food web making them potentially important for energy and matter flux. Recent studies of Bartsch et al. (2016) and Paar et al. (2016) show significant changes in the structure of the macroalgal belt at Hansneset and also its macrozoobenthos community between 1996 and 1998 and 2012-2014. In comparison with previous studies, these changes might be caused by an increase of ice-free days over the last decade and a decrease in ice scouring, but the lack of quantitative baseline data for the shallow water fish community in Kongsfjorden makes it impossible to detect potential changes in relation to shifts in habitats and prey. Potential changes in abundance and species composition of the fish community will have direct effects on other compartments of the food web. To close this gap for future studies, the principal goal of this study is to provide the first quantitative overview of the fish species richness and abundance, as well as spatial distribution patterns of demersal fish in the shallow waters of Kongsfjorden and how it relates to habitat complexity. The data presented in this study were sampled in parallel to the field work published in Bartsch et al. (2016) and Paar et al. (2016) in 2012 and 2013 including the sampling site Hansneset and further sites in the central part of Kongsfjorden. While this study provides baseline data of the fish community, further collaborative publications will cover the role of the fish community in the food web and its seasonal dynamics.

\section{Materials and methods}

The study area was the central part of Kongsfjorden, Svalbard (Fig. 1). In 2012, we sampled in week 24-28 and 36-39. In 2013, sampling was performed from week 23 to 30 and 35-40. In 2012, only one sampling site at the southern shoreline (Old Pier Central; Fig. 1b) and one at the shoreline of the island Blomstrandhalvøya (Hansneset South; Fig. 1b) were chosen, because it was unclear how feasible a more intense sampling program would be. The two sampling sites were chosen for coherence with linked projects. The site Hansneset was used for macroalgal research (Wiencke et al. 2004; Fredriksen et al. 2014; Bartsch et al. 2016; Paar et al. 2016), and at the site Old Pier Central, the Kongsfjorden Underwater Observatory was deployed. Additionally, we expected that the counterclockwise water mass circulation in Kongsfjorden (Willis et al. 2006) might influence the fish community on the opposite shorelines of Kongsfjorden.

With logistical support from the research management company KingsBay and the AWIPEV research station in 2012, we extended the sampling scheme in 2013 to six sampling areas, consisting of three areas at the northern shoreline around Blomstrandhalvøya (Sørvågen, Hansneset and London; Fig. 1b) and three areas at the southern shoreline (Brandal, Old Pier and Gåsebu; Fig. 1b). Starting with week 26 in 2013 one sampling area at each shoreline (Hansneset and Old Pier) was sampled at three subsites (Hansneset North, Hansneset Central and Hansneset South; Old Pier West, Old Pier Central and Old Pier East). The subsites were 50-75 m apart from each other. The triplicate sampling design at the respective middle sites of each shoreline was performed to provide an estimate of the variability within a sampling area. From the beginning of the study up to week 36 of 2012, sampling was performed at each of the two sites using one fyke net [diameter $40 \mathrm{~cm}$, length $90 \mathrm{~cm}$, mesh size $12 \mathrm{~mm}$ (bar mesh)], deployed in about $3 \mathrm{~m}$ water depth with its mouth set perpendicular to the shoreline and one trammel net (inner/outer mesh size $1 / 15 \mathrm{~cm}$, length $20 \mathrm{~m}$, height $2 \mathrm{~m}$ ) deployed from about 5 to $12 \mathrm{~m}$ water depth. The distance to the shoreline depended on the slope of the seafloor, and ranged from 5 to $50 \mathrm{~m}$. 
During an equipment test in week 35 of 2012, we monitored an interaction of young seals with the trammel nets, indicating potential for entanglement. In response, we decided to replace all trammel nets by sets of three fyke nets per sampling site. One fyke net [diameter $40 \mathrm{~cm}$, length $90 \mathrm{~cm}$, mesh size $12 \mathrm{~mm}$ (bar mesh)], was deployed in about $3 \mathrm{~m}$ water depth and a second one of the same type in $12 \mathrm{~m}$ water depth. Additionally, a double fyke net [diameter $60 \mathrm{~cm}$, length $110 \mathrm{~cm}$, mesh size $12 \mathrm{~mm}$ (bar mesh)], connected by a $10 \mathrm{~m}$ long, $80 \mathrm{~cm}$ high steering net (18 $\mathrm{mm}$ bar mesh) was laid out between 5 and $8 \mathrm{~m}$ water depth. All nets were laid out in line with their mouths set perpendicular to the shoreline. We also started to place bait (fish muscle tissue) in the fyke nets at 3 and $12 \mathrm{~m}$ water depth to increase the fish catches in the solitaire fyke nets. The plan was not to compare between nets with and without bait, but only to do analysis between identical sets of nets at different sampling sites. The sampling design was maintained from this point on for all further samplings in 2012 and in 2013.

The net exposure time was normally $24 \mathrm{~h}$. However, logistic and weather conditions occasionally delayed net recovery to exposure times of up to $96 \mathrm{~h}$. To calculate the effects of a delayed net recovery on the mean catch efficiency, we back-calculated all catches to $24 \mathrm{~h}$ exposure time and compared the number of fishes caught per $24 \mathrm{~h}$, per net (CPUE) of the catches with $24 \mathrm{~h} \pm 3 \mathrm{~h}$ exposure time $(N=566), 72 \pm 3 \mathrm{~h}$ exposure time $(N=276)$ and $96 \pm 3 \mathrm{~h}$ exposure time $(N=130)$. Because we had no simultaneous catches for 24, 72 and $96 \mathrm{~h}$ at one site and one timepoint to make a real experimental comparison of the effects of exposure time on the CPUE, we included all catches in the analysis to avoid hidden structural site or time effects, which we could not predict. We used three Bonferroni-corrected unpaired two-group Wilcoxon and Mann-Whitney Tests (Wilcoxon 1945; Mann and Whitney 1947), to compare all CPUE values of the three classes with each other. The tests revealed no significant difference between the three exposure time scenarios (24 vs. $72 \mathrm{~h}$, $W=78,512, \quad p=0.90 ; 24$ vs. $96 \mathrm{~h}, W=33,947.5$, $p=0.16$; 72 vs. $96 \mathrm{~h}, W=17,086, p=0.44)$. All sampled fishes were identified to species level by morphological characteristics (Able 1990; Węsławski et al. 1990; Muus and Nielsen 1999; Hayward and Ryland 2005), except for fishes of the family Liparidae due to the potential for errors.

Standard length (SL) of all fishes was determined to the nearest $0.5 \mathrm{~cm}$, and specimen was weighed with a precision of $1 \mathrm{~g}$ wet weight. For analysing species occurrence over all sampling sites, as well as species-specific size distribution, we used all fishes sampled in 2012 and 2013. Note that the length frequency distribution is only presented for the most abundant species, due to the sample size. For all site comparative analyses, however, we only used the data from week 26 to 40 of 2013, because during this time-period, all sites and subsites were sampled in parallel with an equivalent total fishing effort. Based on the absolute number of fishes caught at the sampling sites in this period, ecological metrics were calculated. Species richness (S) (Colwell 2009) was calculated as the total number of species per site. However, Colwell stated that a comparison of $\mathrm{S}$ values among different sites might be biased by significant differences in total abundance among these sites. Because of differences in the sample sizes between our sampling sites, we additionally calculated the rarefied species richness (Raup 1975). It is based on a random subsampling of the total samples to of every site. By this method, a standardised species richness for a sample size of $N=100$ per site was calculated. Furthermore, the Shannon-Wiener diversity $\left(H^{\prime}\right)$ (Shannon 1948) and the associated species evenness $\left(J=H^{\prime} / \ln (S)\right)$ (Pielou 1966) were determined to evaluate species richness values independent of the total fish abundances at the different sites. These calculations were performed by the software Diversity (Version 1.6.2; Holland 2010).

An Ad Hoc opportunity allowed us to assess the structure of the seafloor in the six sampling areas from 15 July 2013 to 27 July 2013 by SCUBA diving and visual census. This made it possible to gather information about the habitat complexity of our fishing sites. All SCUBA assessments were carried out according to the German diving standard for scientific diving written in BGR/GUVR 2112 (DGUV 2011). For these assessments, we used a 55 $\mathrm{m}$ long line on a diving reel. It was deployed in parallel to the sets of fyke nets. It started in water of $3 \mathrm{~m}$ depth down to the $12 \mathrm{~m}$ bathymetric contour. Depending on the slope of the coastline, the line did not extent to a water depth of $12 \mathrm{~m}$, but was never shallower than the lower end of the double fyke net (minimum $8 \mathrm{~m}$ ). The line had marks every meter and special marks every $10 \mathrm{~m}$ to give the observer distance information. A scientific diver followed the line with a head-mounted video camera, keeping a vertical distance of $1.5 \mathrm{~m}$. The seafloor was thereby captured on video for a distance of about $1 \mathrm{~m}$ on both sides of the transect line. The videos were analysed in $5 \mathrm{~m}$ steps to assess (a) the percentage coverage by algae on an ordinal scale using the classes $<25,25-50,50-75$ and $>75 \%$; (b) the sediment structure using the nominal classifications of sand, gravel, rock, and unidentified. All video analyses were performed repeatedly and independently by five divers. The values of the five divers were integrated by calculation of the modal value to a single value per $1 \times 5$ m segment.

To compare the abundance of fish at the different fishing sites, a CPUE value was calculated per site and sampling week. It is the average number of fish caught in one fyke 
net in $24 \mathrm{~h}$. Because homogeneity of variance and normal distribution were not given, we chose to use the nonparametric Kruskal-Wallis rank sum test (Kruskal and Wallis 1952) for further analysis. First, we grouped the CPUE values according to their sampling sites, and analysed possible differences. Moreover, we grouped the CPUE values based on the location of the sampling site (Blomstrandhalvøya or south shore) and the modal value determined for the algal coverage per site. We repeated this analysis for species diversity, i.e., we determined the total number of species we caught per site and week. We grouped them for the four different analyses according to sampling site, location, and algal coverage. All tests and transformations were performed in R (R Core Team 2015). When significant differences were detected by the Kruskal-Wallis test, we used the Nemenyi tests for multiple comparisons of rank sums for post hoc analysis (Nemenyi 1963). We chose this test as it compensates for family-wise error with Chi squared approximation. For these operations, the R-Package PMCMR (Pohlert 2015) was used. Both analyses were performed with a significance level of $5 \%$.

To further analyse the inter-site differences in species abundance in more detail, we created a Bray-Curtis resemblance matrix based on the total number of each fish species per site, divided by the total fishing effort per site. The data were square-root transformed to reduce the effect of the highly abundant species. The resemblance matrix was used to create a two-dimensional non-metric multidimensional scaling (MDS) plot (Clarke 1993). Additionally, similarities were analysed by hierarchical cluster analysis using group means (Byrne and Uprichard 2012). These operations were performed with the software Primer 6 (Clarke and Gorley 2006). Bar charts and their metrics were calculated using $\mathrm{R}$ ( $\mathrm{R}$ Core Team 2015) with the additional packages gplots (Warnes et al. 2015), lawstat (Hui et al. 2008), and reshape (Wickham 2007).

\section{Results}

Integrated over all fishing campaigns in 2012 and 2013, a total of 2804 fish and 12 species (including the family Liparidae, which counted as a single group) were caught (Table 1). All species caught by the trammel nets in 2012 were also caught with the fyke nets. The only exception represents the two specimen of Amblyraja radiata (thorny skate), which were both caught in trammel nets. The three most common fish species in the catches were $M$. scorpius, with a total contribution of $74.9 \%, G$. morhua with a $17.2 \%$ contribution, and $G$. tricuspis with a $3.8 \%$ contribution. Fish of the family Liparidae represented a total contribution of $2.3 \%$. All other species including Anarhichas lupus, Melanogramus aeglefinus (haddock), $B$. saida, Pollachius virens (saithe), Lumpenus lampraetiformis (snake blenny), A. radiata, Clupea harengus (Atlantic herring), and Cyclopterus lumpus (lumpfish) were caught in much lower abundances, with contributions below $1 \%$ per species (Table 1 ).

The modal value for standard length was $15.0 \mathrm{~cm}$ for $M$. scorpius, $15.0 \mathrm{~cm}$ for G. morhua, $14.5 \mathrm{~cm}$ for G. tricuspis, and $10.0 \mathrm{~cm}$ for Liparidae. (Table 1). Further analysis of the species-specific length data (Fig. 2) revealed a comparatively uniform length-frequency distribution in $M$. scorpius, with a maximum near its arithmetic mean (1st quartile $14 \mathrm{~cm}$, median $16 \mathrm{~cm}$, 3rd Quartile $17.5 \mathrm{~cm}) . G$. morhua showed a much wider and almost bimodal lengthfrequency distribution with a first maximum at $7 \mathrm{~cm}$ and a second maximum between 15 and $17 \mathrm{~cm}$. A similar bimodal length-frequency distribution was also observed for $G$. tricuspis with a first maximum at $6 \mathrm{~cm}$ and a second maximum between 15 and $16 \mathrm{~cm}$.

Based on the dataset of 2013, we compared the different sampling sites in Kongsfjorden (Table 2). The CPUE (average number of fish per net in $24 \mathrm{~h}$ ) of the sites around Blomstrandhalvøya was 1.11 ( $\mathrm{SD}=0.64)$, while the sites at the south shore showed a value of $0.78(\mathrm{SD}=0.54)$ (Fig. 3). A Kruskal-Wallis test showed a significant difference in CPUE between the two coastlines $\left(\chi^{2}(1\right.$, $N=110)=11.47, p<0.01)$. The average number of species counted per sampling week was $2.76(\mathrm{SD}=0.77)$ for the sampling sites at Blomstrandhalvøya, and 2.25 $(\mathrm{SD}=0.77)$ for the sampling sites at the south shore. The Kruskal-Wallis rank sum test reports the two groups as significantly different $\left(\chi^{2} \quad(1, \quad N=110)=10.691\right.$, $p<0.01)$. A site wise comparison of weekly CPUE and number of species could show no statistical significant differences (Fig. 3).

The underwater mapping of the six sampling sites showed distinct differences with respect to algal coverage and sediment structure (Table 3). The grouping of CPUE according to the modal value of algal coverage at the sampling sites shows also differences. The highest average CPUE was detected at the sites with the lowest algal coverage $(1.1, \mathrm{SD}=0.94)$, the second highest at the sites of densest algal coverage $(0.96, \mathrm{SD}=0.49)$. Statistical analysis reveals a significant difference between the sites of $50-75 \%$ algal coverage and $75-100 \%$ coverage $\left(\chi^{2}(9\right.$, $N=66)=12.483, p<0.01)$. The grouping of the total number of species per week and site according to algal coverage showed the highest species diversity at the site with the highest $(75-100 \%)$ and the lowest $(25-50 \%)$ algal coverage. The site with the intermediate (50-75\%) algal coverage showed the lowest average number of 
Table 1 Species list of all catches in 2012 and 2013. The total catch is presented for the two fishing set-ups used in this study. The percentage is calculated by the sum of all specimens caught. The minimum, maximum, and modal value of standard length is presented

\begin{tabular}{|c|c|c|c|c|c|}
\hline \multirow[t]{2}{*}{ Species name } & \multicolumn{2}{|l|}{ Total catch per net set-up } & \multirow[t]{2}{*}{ Total $(\%)$} & \multicolumn{2}{|c|}{ Standard length $(\mathrm{cm})$} \\
\hline & $\begin{array}{l}\text { Trammel nets, fyke nets } \\
10 \text { June 2012-09 September } 2012\end{array}$ & $\begin{array}{l}\text { Double fyke nets, fyke nets w. bait } \\
10 \text { September 2012-06 October } 2013\end{array}$ & & Range & Modal value \\
\hline $\begin{array}{l}\text { Myoxocephalus scorpius } \\
\text { Linnaeus, } 1758\end{array}$ & 557 & 1543 & 74.89 & $5.0-26.5$ & 15.0 \\
\hline $\begin{array}{l}\text { Gadus morhua } \\
\text { Linnaeus, } 1758\end{array}$ & 63 & 420 & 17.23 & $5.5-82.0$ & 15.0 \\
\hline $\begin{array}{l}\text { Gymnocanthus. tricuspis } \\
\text { Reinhardt, } 1830\end{array}$ & 22 & 85 & 3.82 & $4.5-20$ & 14.5 \\
\hline Liparidae & 4 & 59 & 2.25 & $6.0-19$ & 10.0 \\
\hline $\begin{array}{l}\text { Anarhichas lupus } \\
\text { Linnaeus, } 1758\end{array}$ & 3 & 10 & 0.46 & $28.0-61.5$ & 42.0 \\
\hline $\begin{array}{l}\text { Melanogrammus aeglefinus } \\
\text { Linnaeus, } 1758\end{array}$ & 11 & 1 & 0.43 & $6.0-19.0$ & 17.5 \\
\hline $\begin{array}{l}\text { Boreogadus saida } \\
\text { Lepechin, } 1774\end{array}$ & 0 & 10 & 0.36 & $21.0-30.0$ & 25 \\
\hline $\begin{array}{l}\text { Pollachius virens } \\
\text { Linnaeus, } 1758\end{array}$ & 0 & 6 & 0.21 & $6.0-16.5$ & NA \\
\hline $\begin{array}{l}\text { Lumpenus lampretaeformis } \\
\text { Wallbaum, } 1792\end{array}$ & 1 & 4 & 0.18 & $24.0-41.0$ & 40.5 \\
\hline $\begin{array}{l}\text { Amblyraja radiata } \\
\text { Donovan, } 1808\end{array}$ & 2 & 0 & 0.07 & $54.0-54.0$ & 54.0 \\
\hline $\begin{array}{l}\text { Clupea harengus } \\
\text { Linnaeus, } 1758\end{array}$ & 0 & 2 & 0.07 & $19.0-19.0$ & NA \\
\hline $\begin{array}{l}\text { Cyclopterus lumpus } \\
\text { Linnaeus, } 1758\end{array}$ & 0 & 1 & 0.04 & $20.0-20.0$ & 20.0 \\
\hline
\end{tabular}

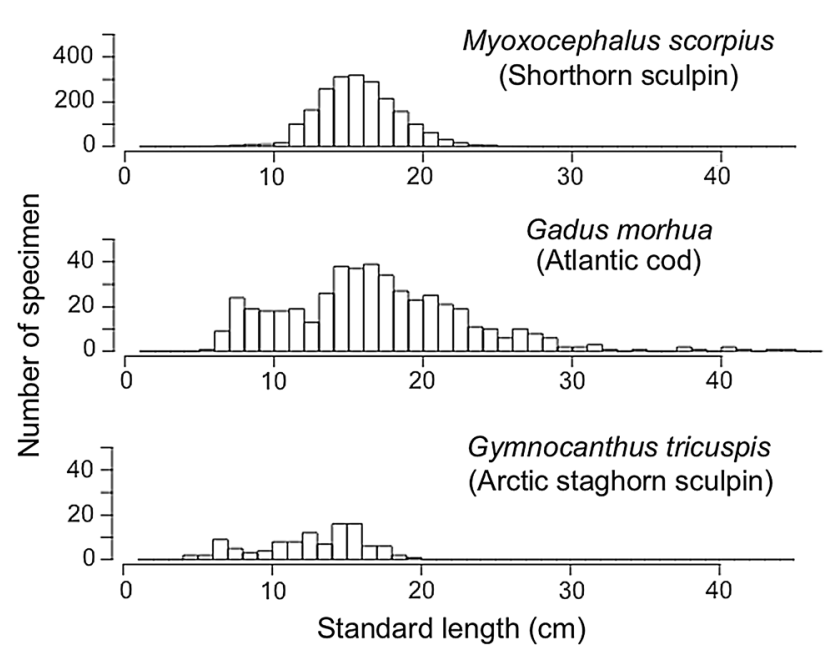

Fig. 2 Cumulative standard length distributions of the three most abundant fish species, M. scorpius, G. morhua and G. tricuspis

species. Statistical analysis showed a distinct difference between 50-75 \% algal coverage and 75-100\% coverage $\left(\chi^{2}(2, N=66)=11.576, p<0.01\right)$.
The total number of species per site varied between four and seven for the whole sampling period (Table 2). The highest values of species richness (seven species) were found at the sites Hansneset Central, Hansneset South, and London along the shoreline of Blomstrandhalvøya. The sites with the lowest total number of species (four species) were Old Pier East (south shore) and Hansneset North (Blomstrandhalvøya) (Table 2). The calculation of the rarefied species richness for a unified sampling size of $N=100$ per site showed similar results with the highest values at the sites Hansneset Central (6.3) and London (6.2) and the lowest values at the sites Old Pier East (3.5) and Old Pier West (4.0) (Table 2). The calculated values for Shannon's $H^{\prime}$ integrate information about species richness and abundance. An apparent gradient was observed along the southern shoreline with the lowest $H^{\prime}$ value of 0.51 at the site Brandal and the highest value of 1.05 at the innermost sampling site, Gåsebu (Table 2). At the shoreline of Blomstrandhalvøya, $H^{\prime}$ values between 0.75 and 1.01 were observed with four of five stations having values between 0.95 and 1.01. A comparable west- 


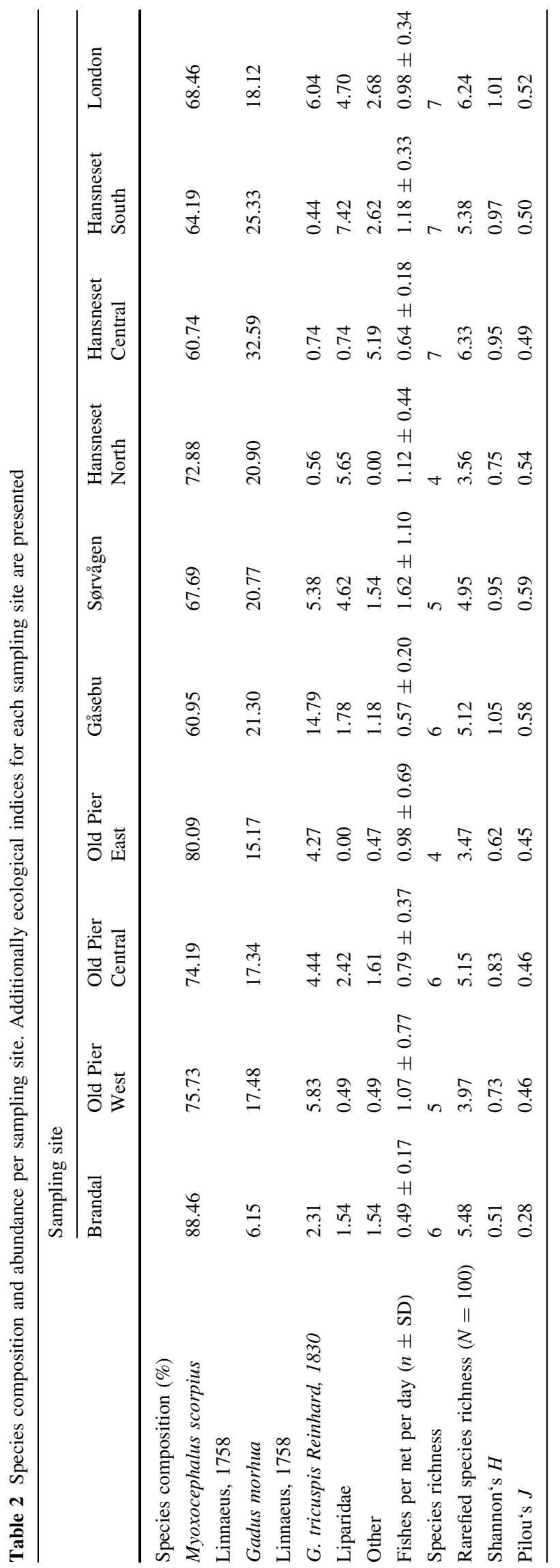

east trend along the southern shoreline was observed for Pilou's $J^{\prime}$ (Pielou 1975), a measure of species evenness. The lowest value was determined for the site Brandal (0.28) and highest value at Gåsebu (0.58). Along the north shore, values ranged between 0.49 at Hansneset Central and 0.59 at Sørvågen (Table 2).

The calculated two-dimensional MDS plot shows a Kruskal stress value of 0.09 (Fig. 4). Ordination of sites occurred in groups according to their general geographical locations from west (left) to east (right). An exception are the sites at Hansneset that cluster on the lower right of the plot. Hierarchical cluster analysis of the Bray-Curtis resemblance matrix was used to add further information to the MDS plot. The overall similarity between all sites was determined to be over $77 \%$. Using a similarity level of $>80 \%$, two clusters could be discriminated (Fig. 4). One contained Hansneset South, Hansneset North, and Hansneset Central. The second contained all other sites, except the site Brandal, which is not part of any cluster. Two subclusters at a similarity level of $>90 \%$ could be identified. The first contained the sites London and Sørvågen, and the second contained Old Pier West and Old Pier Central.

\section{Discussion}

This study provides the first systematic field data of the shallow water fish community of this polar ecosystem. According to Hop et al. (2002), such data on the higher trophic levels of shallow water polar ecosystems are completely missing but urgently needed for a basic understanding of the functional responses of Arctic ecosystems to environmental changes like global warming.

Our most striking result is the distinct dominance of the shallow water fish community in Kongsfjorden by the two species M. scorpius and G. morhua, while other species that were found in previous studies were rare or absent. This is in good agreement with Hop et al. (2002). The apparent lack of B. saida in our study, e.g., is most remarkable because previous studies reported high abundances of B. saida in the offshore and coastal waters of Kongsfjorden (Haug and Gulliksen 1982). Similarly, we could not detect any Mallotus villosus, Sebastes sp. (redfish) or Hippoglossoides platessoides (American plaice), which were reported in previous studies (Hop et al. 2002). A key to understand these differences in species occurrence in comparison with previous studies may be the lifestyles of these species. $B$. saida is known to prefer sea ice as habitat for young-of-year (YOY) and older specimen which are often found below sea ice at sub-zero temperatures (Lønne and Gulliksen 1989; Hop and Gjøsæter 2013). The apparent lack of sea ice in Kongsfjorden since the winter of 
a
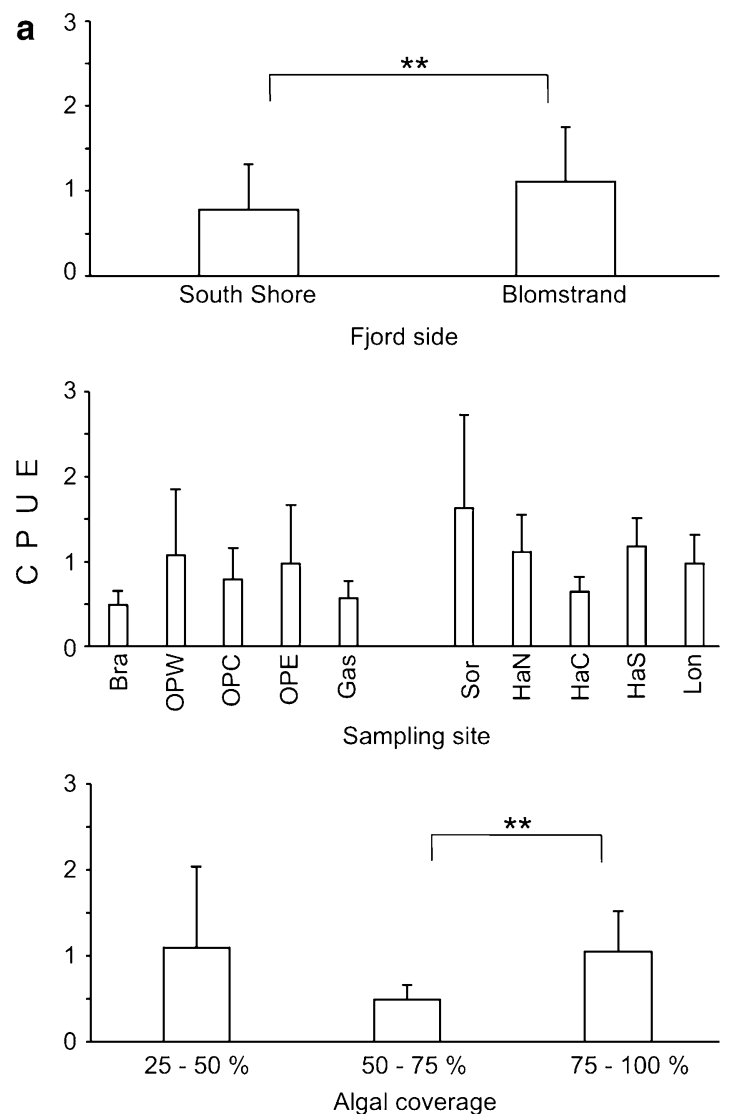

b

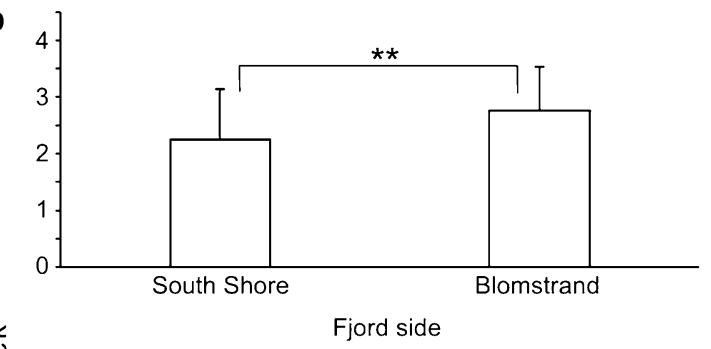

$\frac{x}{0}$
0
3
$\overline{0}$
0
0
0
$\frac{1}{0}$
0
0
0
4
0
0
$\vdots$
$z$
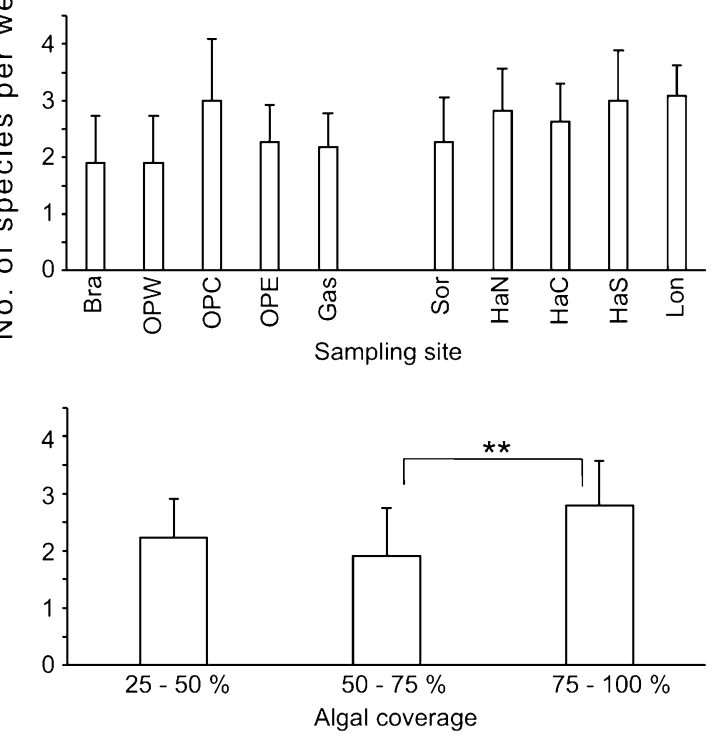

Fig. 3 a Number of fish per net SD in 24 h (CPUE) and b Total number of species per week. Values are grouped by their geographical location (upper panel), their sampling site (middle panel) or the modal value of algal coverage at their respective sampling site (lower panel)

2005/2006 might therefore be a factor that explains the low abundances of $B$. saida in Kongsfjorden (Cottier et al. 2007). Additionally, Fischer et al. (2016) reports temperatures of 4 to $8{ }^{\circ} \mathrm{C}$ from June to September 2014 at $10 \mathrm{~m}$ water depth at the Old Pier in Ny-Ålesund. This clearly exceeds the preferred temperature range of $B$. saida and might additionally explain its low abundances. Also Hop et al. (2002) reports that $B$. saida and $M$. villosus could be found in the pelagic realm of the fjord, which was not sampled in this study. For a similar reason, H. platessoides might not be represented in this study. This species prefers deeper waters below $90 \mathrm{~m}$, and it is likely that it is therefore not caught in the shallow waters of Kongsfjorden. In contrast, M. scorpius is a classic demersal fish species of shallow water habitats (Lamp 1966). Therefore, the dominance of this species in our fyke net catches is not surprising. Also, young specimen of G. morhua are well known to seek protection in structural complex shallow water habitats to avoid predators and cannibalisation by larger specimen, explaining the high abundance of this species with younger age classes in the shallow waters.

Another explanation for the dominance of $M$. scorpius and G. morhua in our study might be gear selectivity. It is known that fyke nets are size and species selective (Hubert et al. 2012). Cover-seeking mobile species are reported to be most susceptible to capture by this gear type (Hubert et al. 2012). On the other hand, we minimised size selectivity by small mesh size, and we could not detect a change in species composition with regard to the trammel nets that we used in 2012. The dominance of M. scorpius in the shallow areas of Kongsfjorden was also confirmed by continuous diving operations during the last 15 years (Max Schwanitz, pers. com.). Therefore, we doubt that the generally low share of Arctic fishes $(<5 \%)$ in our catches in the shallow water system of Kongsfjorden was an artefact.

Parallel to our study Mark (2013) performed trawling catches with RV Heincke in outer Kongsfjorden and also caught G. morhua (and the pelagic species Melanogrammus aeglefinus) in higher abundances and missed B. saida, or $M$. villosus in the catches. Even though this study used a completely different fishing gear, it is most interesting that the species composition was similar to our study with a high dominance of G. morhua during 2013. The standard length (SL) of G. morhua captured offshore was reported as $5.5-9.5 \mathrm{~cm}$, which was quite below the average length of $15.0 \mathrm{~cm}$ in our study. Surveys at the Lofoten in January 
Table 3 Algal coverage and sediment structure at the sampling sites from 3 to $12 \mathrm{~m}$ water depth. The bottom structure was determined by SCUBA video survey and subsequent video analysis

\begin{tabular}{lllllll}
\hline Distance from shore $(\mathrm{m})$ & Brandal & Old Pier East & Gåsebu & Sørvågen & Hansneset South & Lonc \\
\hline (a) Algal coverage & 1 & 3 & 2 & 4 & 4 & 2 \\
5 & 1 & 4 & 2 & 2 & 4 & 2 \\
10 & 2 & 4 & 2 & 4 & 4 & 3 \\
15 & 3 & 4 & 2 & 2 & 4 & 3 \\
20 & 3 & 4 & 2 & 4 & 4 & 3 \\
25 & 2 & 4 & 2 & 3 & 4 & 4 \\
30 & 3 & 4 & 1 & 2 & 4 & 4 \\
35 & NA & 4 & 2 & 2 & 4 & 4 \\
40 & NA & 4 & 2 & 3 & 4 & 4 \\
45 & NA & 4 & 2 & 4 & 4 & 4 \\
50 & NA & 4 & 2 & 2 & 4 & 4 \\
55 & 3 & 4 & 2 & 2 & 4 & 4 \\
Modal value & & 1 & 2 & 3 & 4 & $45-100 \%$
\end{tabular}

(b) Sediment structure

$\begin{array}{lll}5 & 1 & 1 \\ 10 & 1 & 1 \\ 15 & 1 & 1 \\ 20 & 1 & 1 \\ 25 & 1 & 4 \\ 30 & 1 & 1 \\ 35 & 1 & 1 \\ 40 & \text { NA } & 1 \\ 45 & \text { NA } & 2 \\ 50 & \text { NA } & 2 \\ 55 & \text { NA } & 1 \\ & 1 & 1 \\ \text { Key } & & 1\end{array}$

$\begin{array}{lllll}1 & 1 & 4 & 4 & 1 \\ 1 & 1 & 4 & 4 & 1 \\ 1 & 1 & 1 & 2 & 1 \\ 1 & 1 & 1 & 2 & 1 \\ 4 & 1 & 1 & 4 & 1 \\ 1 & 1 & 1 & 4 & 1 \\ 1 & 1 & 1 & 4 & 4 \\ 1 & 1 & 1 & 4 & 4 \\ 2 & 1 & 1 & 4 & 4 \\ 2 & 1 & 4 & 4 & 4 \\ 1 & 1 & 4 & 4 & 4 \\ 1 & 1 & 1 & 4 & \\ 1 & 2 & 3 & 4 & \\ \text { Sand } & \text { Gravel } & \text { Rock } & \text { Fully covered } & \end{array}$

2002 revealed a mean standard lengths of $12.4 \mathrm{~cm}$ at age $1+, 19.9 \mathrm{~cm}$ at age $2+$ and $31.4 \mathrm{~cm}$ at age $3+$ (ICES 2005). Assuming a similar growth rate, the majority of Atlantic cod caught in our study belonged to the age classes $1+$ and $2+$ (Fig. 2) and age- 0 fish were almost completely missing. This is interesting with respect to the fact that it is generally assumed that cod in Svalbard belongs to the Arcto-Norwegian cod stock, which is known to spawn along the Norwegian coast from Møre up to East Finnmark (Sarvas and Fevolden 2005; Sundby and Nakken 2008). Assuming that our shallow water specimen and the offshore YOY specimen from the Heincke cruise belonged to the same stock, this would imply a long distance migration of the YOY from offshore towards the Kongsfjorden ecosystem. It is unfortunate that there is to our knowledge no study in a similar area of the Arctic that focuses on the interactions and exchange between the fish communities of the shallow waters, deep waters, and pelagic realms.
However, it is generally known that fish of the same size classes spatially separate in different habitats. Especially, smaller fishes often prefer complex shallow water habitats to avoid predation and cannibalism as well as to use these habitats to access suitable food sources. That we did not catch specimen of $G$. morhua with a SL $<10 \mathrm{~cm}$ in our nets could be explained by the theory that they gain a size of about $10 \mathrm{~cm}$ SL before migrating into the shallow water habitat of Kongsfjorden. Another explanation might be that we simply were not able to catch YOY specimen of G. morhua due to gear selectivity. The fyke nets and trammel nets we used had mesh sizes of 10 and $12 \mathrm{~mm}$. The body height of $G$. morhua with standard length below $10 \mathrm{~cm}$ is expected to be smaller than $10 \mathrm{~mm}$; therefore, they might have passed our nets without any detection.

Our study shows an increase in biodiversity along the south shore of the fjord from the west to the east. The water mass dynamics of Kongsfjorden may be the key to 
Fig. 4 Multivariate analysis (MDS) of total catch per fish species per sampling site, based on square-root transformed data and Bray-Curtis dissimilarity index. Hierarchical cluster analysis was used to identify cluster with a similarity of $>80$ and $>90$ of 100



understanding this pattern in species distribution. Willis et al. (2006) showed the existence of a cyclonic and counter-clockwise gyre in the Kongsfjorden. Atlantic and Arctic water masses are mixed at the fjord mouth and are driven along the south shore to the inner parts of the fjord. Along the south shore, fresh water from the glaciers mixes continuously with the imported water masses. This results in a continuous reduction of salinity and a decrease in temperature, forming a gradient towards the inner parts of the fjord. Our study showed an increase of biodiversity and species evenness along this gradient from the westerly to the easterly sampling stations. M. scorpius, the most abundant and typically Atlantic species in this study, showed its highest abundance at the westernmost station Brandal, which is most influenced by Atlantic and, thereby, warmer and more saline water masses. The lowest CPUE for M. scorpius was found at the most eastern station Gåsebu. This station is most influenced by glacial melt water and, thereby, characterised by lower water temperatures and lower salinities. The reverse trend was found for G. tricuspis, a typical Arctic cottid fish species with antifreezing proteins. Its highest abundance was found at the easternmost stations Gåsebu, its lowest abundances at the westernmost station Brandal. Low salinities and low water temperatures are characteristic for Arctic water masses. Thereby, this hydrographic gradient in Kongsfjorden resembles a small scale Atlantic-Arctic gradient. The reciprocal maximum in CPUE of M. scorpius and G. tricuspis along the south shore indicates a concurrency between the two species. This hypothesised co-occurrence between $M$. scorpius and G. tricuspis is most interesting with respect to the spatial distribution of fish along polar gradients. M. scorpius is a generalist with respect to food sources with a fast reproductive cycle, and it can tolerate a wide range of salinities and temperatures (Ennis 1970; Luksenburg and Pedersen 2002). In contrast, G. tricuspis is an cold-adapted Arctic species with a smaller range of tolerated hydrography. It is possible that the two species are in competition regarding the same ecological resources such as food, and the differences in physiological adaption in combination with hydrography lead to this difference in small-scale geographical distribution. One factor could be the costs versus the advantages of the anti-freezing proteins of $G$. tricuspis. But it has to be noted that adaptive mechanisms to low temperatures and their metabolic costs are not yet universally accepted (Steffensen 2002). Moreover, the species-specific expression of cold adaptations with respect to seasonality and environmental parameters is still subject of research (di Prisco 2000; Enevoldsen et al. 2003).

On the shoreline of Blomstrandhalvøya, the sites Sørvågen and London that were constantly influenced by the water mass export from inner Kongsfjorden showed the highest abundance of G. triscuspis. Also they showed the closest resemblance to Gåsebu with respect to species abundance (Fig. 4). The sampling site Hansneset showed the most distinct pattern in species abundance and diversity that might be driven by its exposed position towards the mouth of the fjord, and a thereby diverse influence of different water masses at this site (Willis et al. 2006).

A further factor that influences the abundance and species diversity of the different sampling sites is the algal coverage. It is known that habitat structure is one of the most important factors for the temporal and spatial 
distribution of fish abundance (Crowder and Cooper 1982; Johnson and Beaumier 1988; Persson and Eklöv 1995; Fischer 2000, 2004). In this study, we were able to show that the sites with highest species abundance with respect to CPUE were the sites with an algal coverage of $75-100 \%$, and the sites with the second highest coverage the one with $25-50 \%$. It can be assumed that the sites with the highest coverage and most structural complexity provided the best protection for fish, but also for prey. Sites with lower structural complexity represented therefore an easier feeding ground for fish, explaining the high CPUE at sites with 25-50\% algal cover. Only one site in this study (Brandal) showed an algal coverage of 50-75\%. The low CPUE at this class of algal coverage might thereby be an site-specific effect. Alternatively, it could be explained by the assumption that the intermediate algal coverage was not optimal for hunting and also not for structural protection. Therefore, it might have shown the least abundance of fish.

For sure, the assessment of this study can only be seen as a snapshot within a limited time scale and a limited number of sampling stations. Nevertheless, a more detailed future study about the influence of algae coverage on the Kongsfjorden shallow water ecosystem is advised. Future replications of this study should integrate a thorough habitat mapping and detailed hydrographic assessments to further analyse the link between fishes and habitat variables in Kongsfjorden. Further investigations on the importance of algal belts in Kongsfjorden as nursing grounds for fish are also warranted, and ongoing long-term observation by automatic camera systems like the Kongsfjorden Underwater Observatory (Fischer et al. 2016), could potentially improve our understanding of the year-round cycles of the fish and macrozoobenthos communities of Kongsfjorden. A publication about the inter-annual variability, assessed by automatic camera systems (Wehkamp and Fischer 2014) and fyke net fishing from 2012 to 2014 is currently in preparation. But also the replication of this study in shallow water systems of other Arctic fjords is necessary to understand if Kongsfjorden shows special characteristics or common trends. It is possible that the results of this study, especially, the dominance of boreal species are connected to changes in the algal belts and the macrozoobenthos community that have been documented by Bartsch et al. (2016) and Paar et al. (2016). To further explore the connection between the sampling sites and the fish community cooperative publications regarding growth rates, nutritional status, and trophic relationships of shallow water fishes at Hansneset are currently in preparation. In combination with future reassessments, this study can be used as a baseline for the detection of borealisation in Kongsfjorden.

Acknowledgments This work was performed at the International Arctic Environmental Research and Monitoring Facility in $\mathrm{Ny}-$
Ålesund, Spitsbergen, Norway. We thank the crew of the AWIPEV Arctic Research Base for their great support of our fieldwork. Furthermore, we appreciate the helpful comments of the reviewers of this manuscript. We would also like to thank Michael Greenacre for statistical support.

\section{Compliance with ethical standards}

Ethical approval All applicable international, national, and/or institutional guidelines for the care and use of animal were followed.

\section{References}

Able KW (1990) A revision of Arctic snailfishes of the genus Liparis (Scorpaeniformes: cyclopteridae). Copeia 1990:476-492. doi:10. $2307 / 1446352$

ACIA (2004) Impacts of a Warming Arctic. Cambridge University Press, Cambridge

Bartsch I, Paar M, Fredriksen S, Schwanitz M, Daniel C, Hop H, Wiencke C (2016) Changes in kelp forest biomass and depth distribution in Kongsfjorden, Svalbard, between 1996-1998 and 2012-2014 reflect Arctic warming. Polar Biol. doi:10.1007/ s00300-015-1870-1

Byrne D, Uprichard E (2012) Cluster Analysis. SAGE Publications Ltd, London

Cheung WWL, Lam VWY, Sarmiento JL, Kearney K, Watson R, Pauly D (2009) Projecting global marine biodiversity impacts under climate change scenarios. Fish Fish 10:235-251

Christiansen JS, Mecklenburg CW, Karamushko OV (2014) Arctic marine fishes and their fisheries in light of global change. Global Change Biol 20:352-359. doi:10.1111/geb.12395

Clarke KR (1993) Nonparametric multivariate analyses of changes in community structure. Aust J Ecol 18:117-143. doi:10.1111/j. 1442-9993.1993.tb00438.x

Clarke KR, Gorley RN (2006) PRIMER v6: User Manual/Tutorial. PRIMER-E, Plymouth

Colwell RK (2009) Biodiversity: Concepts, patterns and measurement. In: Levin Simon A (ed) The Princeton guide to ecology, 1st edn. Princeton University Press, Princeton, pp 257-263

Cottier F, Tverberg V, Inall M, Svendsen H, Nilsen F, Griffiths C (2005) Water mass modification in an Arctic fjord through cross-shelf exchange: the seasonal hydrography of Kongsfjorden. Svalbard. J Geophys Res 110:C12005. doi:10.1029/2004JC002757

Cottier FR, Nilsen F, Inall ME, Gerland S, Tverberg V, Svendsen H (2007) Wintertime warming of an Arctic shelf in response to large-scale atmospheric circulation. Geophys Res Lett 34. doi:10.1029/2007GL029948

Crowder LB, Cooper WE (1982) Habitat structural complexity and the interaction between bluegills and their prey. Ecology 63:1802-1813. doi:10.2307/1940122

DGUV expert committee for underground engineering (2011) BGR/ GUV-R 2112_Einsatz von Forschungstauchern. Deutsche Gesetzliche Unfallversicherung e.V. (DGUV), Berlin

di Prisco G (2000) Life style and biochemical adaptation in Antarctic fishes. J Mar Syst 27:253-265. doi:10.1016/S0924-7963(00)0 0071-3

Enevoldsen LT, Heiner I, DeVries AL, Steffensen JF (2003) Does fish from the Disko Bay area of Greenwald possess antifreeze proteins during the summer? Polar Biol 26:365-370

Ennis GP (1970) Age, growth, and sexual naturity of the shorthorn sculpin, Myoxocephalus scorpius, in Newfoundland waters. J Fish Res Bd Can 27:2155-2158. doi:10.1139/f70-244

Fischer P (2000) Test of competitive interactions for space between two benthic fish species, burbot Lota lota, and stone loach 
Barbatula barbatula. Environ Biol Fish 58:439-446. doi:10. 1023/A:1007631107521

Fischer P (2004) Effects of intraspecific competition and predation risk in the littoral-benthic community: a case study of juvenile burbot (Lota Iota). Boreal Environ Res 9:213-225

Fischer P, Eckmann R (1997a) Seasonal changes in fish abundance, biomass and species richness in the littoral zone of a large European lake, Lake Constance, Germany. Arch Hydrobiol 139:433-448

Fischer P, Eckmann R (1997b) Spatial distribution of littoral fish species in a large European lake, Lake Constance, Germany. Arch Hydrobiol 140:91-116

Fischer P, Schwanitz M, Posner U, Loth R, Brand M, Schröder F (2016) The first year of the new Arctic AWIPEV-COSYNA Underwater Observatory in Kongsfjorden. Ocean Sci Discuss, Spitsbergen. doi:10.5194/os-2016-52

Fossheim M, Primicerio R, Johannesen E, Ingvaldsen RB, Aschan MM, Dolgov AV (2015) Recent warming leads to a rapid borealization of fish communities in the Arctic. Nat. Clim Chang 5:673-678. doi:10.1038/nclimate2647

Fredriksen S, Bartsch I, Wiencke C (2014) New additions to the benthic marine flora of Kongsfjorden, western Svalbard, and comparison between 1996/1998 and 2012/2013. Bot Mar 57(3):203-216. doi:10.1515/bot-2013-0119

Haug T, Gulliksen B (1982) Size, age, occurrence, growth, and food of Greenland halibut, Reinhardtiushippoglossoides (Walbaum) in coastal waters of western Spitzbergen. Sarsia 67:293-297. doi:10.1080/00364827.1982.10421343

Hayward PJ, Ryland JS (2005) Handbook of the Marine Fauna of North-West Europe. Oxford University Press Inc., New York

Holland S (2010) Diversity. Hunt Mountain Software, Athens

Hop H, Gjøsæter H (2013) Polar cod (Boreogadus saida) and capelin (Mallotus villosus) as key species in marine food webs of the Arctic and the Barents Sea. Mar Biol Res 9:878-894. doi:10. 1080/17451000.2013.775458

Hop H, Pearson T, Hegseth EN et al (2002) The marine ecosystem of Kongsfjorden, Svalbard. Polar Res 21:167-208. doi:10.1111/j. 1751-8369.2002.tb00073.x

Hop H, Wiencke C, Vögele B, Kovaltchouk NA (2012) Species composition, zonation, and biomass of marine benthicmacroalgae in Kongsfjorden. Svalbard Bot. Mar 55:399-414. doi:10. 1515/bot-2012-0097

Hubert WA, Pope KL, Dettmers JM (2012) Passive Capture Techniques. Nebraska Coop Fish Wildl Res Unit 11:244-246

Hui W, Gel YR, Gastwirth JL (2008) lawstat: an R Package for law, public policy and biostatistics. J Stat Softw 28:1-26

ICES (2005) Spawning and life history information for North Atlantic cod stocks. ICES Cooperative Research Report 274

Johnson DL, Beaumier RA (1988) Selection of habitat structure interstice size by bluegills and largemouth bass in ponds. Trans Am Fish Soc. doi:10.1577/1548-8659

Jørgensen LL, Gulliksen B (2001) Rocky bottom fauna in Arctic Kongsfjord (Svalbard) studied by means of suction sampling and photography. Polar Biol 24:113-121. doi:10.1007/ s003000000182

Keast A (1985) The piscivore feeding guild of fishes in small freshwater ecosystems. Environ Biol Fish 12:119-129. doi:10. 1007/BF00002764

Kruskal WH, Wallis AW (1952) Use of Ranks in One-Criterion variance analysis. J Amer Statist Assoc 47:583-621. doi:10. 2307/2280779

Lamp F (1966) Beitrage zur Biologie der Seeskorpione Myoxocephalus scorpius (L.) und Taurulus bubalis(Euphr.) in der Kieler Forde. Kieler Meeresforsch 22:1-29

Lippert H, Iken K, Rachor E, Wiencke C (2001) Macrofauna associated with macroalgae in the Kongsfjord(Spitsbergen). Polar Biol 24:512-522
Lønne OJ, Gulliksen B (1989) Size, Age and Diet of Polar Cod, Boreogadus saida (Lepechin 1773), in Ice Covered Waters. Polar Biol 9:187-191

Luksenburg JA, Pedersen T (2002) Sexual and geographical variation in life history parameters of the shorthorn sculpin. J Fish Biol 61:1453-1464. doi:10.1111/j.1095-8649.2002.tb02489.x

Mann HB, Whitney DR (1947) On a test of whether one of two random variables is stochastically larger than the other. Ann Math Statist 18:50-60

Mark FC (2013) Physical oceanography during HEINCKE cruise HE408. Alfred Wegener Institute, Helmholtz Center for Polar and Marine Research, Bremerhaven, doi:10.1594/PANGAEA. 824703

Muus BJ, Nielsen JG (1999) Sea Fish. Scandinavian Fishing Year Book, Hedehusene

Nemenyi, PB (1963) Distribution-free multiple comparisons. PhD thesis, Princeton University

Paar M, Voronkov A, Hop H, Brey T, Bartsch I, Schwanitz M, Wiencke C, Lebreton B, Asmus R, Asmus H (2016) Temporal shift in biomass and production of macrozoobenthos in the macroalgal belt at Hansneset, Kongsfjorden, after 15 years. Polar Biol. doi:10.1007/s00300-015-1760-6

Persson L, Eklöv P (1995) Prey refuges affecting interactions between piscivorous perch and juvenile perch and roach. Ecology 76:70-81. doi:10.2307/1940632

Pielou EC (1966) The measurement of diversity in different types of biological collections. J Theoret Biol 13:131-144. doi:10.1016/ 0022-5193(66)90013-0

Pielou EC (1975) Ecological Diversity. Wiley, New York

Pierce GJ, Hastie LC, Guerra A, Thorpe RS, Howard FG, Boyle PR (1994) Morphometric variation in Loligo forbesi and Loligo vulgaris: regional, seasonal, sex, maturity and worker differences. Fish Res 21:127-148. doi:10.1016/01654617836(94)90100-7

Pohlert T (2015) PMCMR: Calculate Pairwise Multiple Comparisons of Mean Rank Sums. R package version 1.2. http://CRAN.Rproject.org/package $=$ PMCMR

R Core Team (2015) R: A Language and Environment for Statistical Computing. R Foundation for Statistical Computing, Vienna, Austria. https://www.R-project.org/

Raup DM (1975) Taxonomic diversity estimation using rarefaction. Paleobiology 1:333-342. doi:10.2307/2400135

Renaud P, Tessmann M, Evenset A, Christensen G (2011) Benthic food-web structure of an Arctic fjord (Kongsfjorden, Svalbard). Mar Biol Res 7:13-26. doi:10.1080/17451001003671597

Sarvas TH, Fevolden SE (2005) Pantophysin (Pan I) locus divergence between inshore v. offshore and northern v. southern populations of Atlantic cod in the north-east Atlantic. J Fish Biol 67:444-469. doi:10.1111/j.1095-8649.2005.00738.x

Shannon CE (1948) A mathematical theory of communication. Bell Syst Tech J 27:379-423. doi:10.1002/j.1538-7305.1948.tb01338.x

Steffensen JF (2002) Metabolic cold adaption of polar fish based on measurements of aerobic oxygen consumption: fact or artefact? Artefact! Comp Biochem Physiol A 132:789-795

Stempniewicz L, Błachowiak-Samołyk K, Węsławski JM (2007) Impact of climate change on zooplankton communities, seabird populations and Arctic terrestrial ecosystem - A scenario. DeepSea Res Pt II 4754:2934-2945. doi:10.1016/j.dsr2.2007.08.012

Sundby S, Nakken O (2008) Spatial shifts in spawning habitats of Arcto-Norwegian cod related to multidecadal climate oscillations and climate change. ICES J Mar Sci 65:953-962. doi:10. 1093/icesjms/fsn085

Svendsen H, Beszczynska-Møller A, Hagen JO et al (2002) The physical environment of Kongsfjorden/Krossfjorden, an Arctic fjord system in Svalbard. Polar Res 21:133-166. doi:10.1111/j. 1751-8369.2002.tb00072.x 
Voronkov A, Hop H, Gulliksen B (2013) Diversity of hard-bottom fauna relative to environmental gradients in Kongsfjorden. Svalbard Polar Res 32:11208. doi:10.3402/polar.v32i0.11208

Warnes GR, Ben B, Bonebakker L, Gentleman R, Liaw WHA, Lumley T, Maechler M, Magnusson A, Moeller S, Schwartz M, Venables B (2015) gplots: various R programming tools for plotting data. Rpackage version 2.17.0

Wehkamp M, Fischer P (2014) A practical guide to the use of consumer-level digital still cameras for precise stereogrammetric in situ assessments in aquatic environments. Underwater Technol 32(2):111-128

Werner EE (1977) Species packing and niche complementarity in three sunfishes. Am Nat 111:553-578. doi:10.1086/283184

Werner EE, Gilliam JF, Hall DJ, Mittelbach GG (1983) An experimental test of the effects of predation risk on habitat use in fish. Ecology 64:1540. doi:10.2307/1937508

Węsławski JM, Linkowski TB, Herra T (1990) Fishes. In: Klekowski RZ, Węsławski JM (eds) Atlas of the Marine Fauna of Southern Spitsbergen, vol 1., VertebrateUniversity of Gdańsk, Institute of Oceanology, Gdańsk, pp 67-195

Wickham H (2007) Reshaping data with the reshape package. J Stat Softw 21:1-20
Wiencke C, Vögele B, Kovaltchouk NA, Hop H (2004) Species composition and zonation of marine benthic macroalgae at Hansneset in Kongsfjorden, Svalbard. Ber Polarforsch Meeresforsch 492:55-62

Wilcoxon F (1945) Individual comparisons by ranking methods. Biometrics Bull 1:80-83. doi:10.2307/3001968

Willis K, Cottier F, Kwasniewski S, Wold A, Falk-Petersen S (2006) The influence of advection on zooplankton community composition in an Arctic fjord (Kongsfjorden, Svalbard). J Marine Syst 61:39-54

Wong PP, Losada IJ, Gattuso J-P, Hinkel J, Khattabi A, McInnes KL, Saito Y, Sallenger A (2014) Coastal systems and low-lying areas. In: Field CB, Barros VR, Dokken DJ, Mach KJ, Mastrandrea MD, Bilir TE, Chatterjee M, Ebi KL, Estrada YO, Genova RC, Girma B, Kissel ES, Levy AN, MacCracken S, Mastrandadrea PR, White LL (eds) Climate change 2014: impacts, adaptation, and vulnerability. Part A: global and sectoral aspects. Contribution of Working Group II to the Fifth Assessment Report of the Intergovernmental Panel on Climate Change. Cambridge University Press, Cambridge, pp 361-409 